University of Zurich

Department of Economics

Working Paper Series

ISSN 1664-7041 (print)

ISSN 1664-705X (online)

Working Paper No. 366

\title{
Attaining Autonomy in the Empire: French Governors between 1860 and 1960
}

Scott Viallet-Thévenin and Cédric Chambru

October 2020 


\title{
Attaining Autonomy in the Empire: French Governors between 1860 and 1960*
}

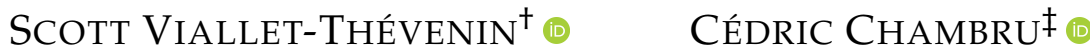

October 2020

\begin{abstract}
This article builds on the concept of linked ecologies to present a study of the occupational careers of French colonial governors between 1830 and 1960. We consider empires as the by-product of social entities structuring themselves. Specifically, we analyse the process of empowerment of this emerging group with respect to other professional groups within the imperial space and the French metropolitan space. Using data on the career of 637 colonial governors between 1830 and 1960, we examine how variations in the recruitment of these high civil servants actually reflect the empowerment of this social entity. We rely on optimal matching technique to distinguish typical sequence models and identify ten common career trajectories that can be grouped in four main clusters. We further compare the share of each clusters in the population of governors over time and show that the rise of the colonial cluster during the Interwar period corresponded to the peak of the administrative autonomy in the colonial space. We argue that this process is consistent with the empowerment of the governors' corps, which is embodied by a common career within the colonial administration and a collective identity as a group.
\end{abstract}

Keywords: State employment decisions; Empowerment; French colonial Empire; 19th century; 20th century.

JEL: D73, F54, H83, J45, M51, N43, N44.

*This paper benefited from helpful feedback and suggestions from Thomas Collas, Sophie Dulucq, Guillaume Favre, Lucine Endelstein, Pierre François, Claire Lemercier, Florence Renucci, and Nathalie Rezzi. We thank participants of 'The digital humanities at the service of colonial and post-colonial studies' meeting in Aix-enProvence and seminar audience at the University of Toulouse 2 for helpful comments.

${ }^{\dagger}$ Scott Viallet-Thévenin, Faculté de Gouvernance, Sciences Économiques et Sociales, University Mohammed VI Polytechnique, Lot 660, Hay Moulay Rachid, 43150 Benguerir, Morocco. scott.viallet-thevenin@m4x.org.

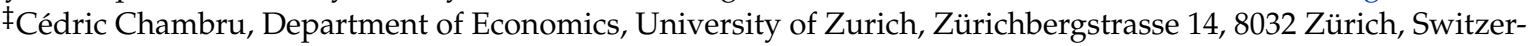
land. Email: cedric.chambru@econ.uzh.ch. 


\section{Introduction}

Ernest Roume was born in Marseille in 1858 the son of a merchant. He entered the Council of State (Conseil d'État) after graduating from École Polytechnique. During his career in the administration, he became director for external trade, and director for Asian affairs at the Minister for Colonies. He then held the position of governor-general for the federation of French West Africa, from 1902 to 1908. He governed Indochina from 1914 to 1917 after a leave from the administration. After 1917, he pursued his career in various colonial firms. ${ }^{1}$

Jules Carde began his career in Algeria, where he was born in 1872 the son of a colonial administrator. From 1892 to 1895 he was a clerk, at the very bottom of the colonial administrative hierarchy. He went to Madagascar in 1895, where he slowly climbed the hierarchy until becoming colonial administrator in 1907. He then spent a year in Martinique before being posted in French West Africa. He spent the rest of his career in colonial central administrations: chief of staff of the governor-general of French Equatorial Africa from 1911 to 1913, he became general secretary for French Equatorial Africa, second in rank to the governor, in 1914. He reached the rank of governor in 1916, being given French Congo. His posting lasted only one year and until 1919 he was general secretary for French West Africa. He was then appointed governor for Cameroon, recently retrieved from the defeated German Empire. From 1923 to 1930, he was governor-general for French West Africa and governor-general for Algeria from 1930 to $1935 .^{2}$

What could explain such a difference in careers? Roume was a metropolitan civil servant, with a very high status, as indicated per the school he graduated from and the career he made, but had no colonial experience. The career of Carde is very different: he did not graduate from a prestigious university and began very low in the hierarchy of the colonial administration, with no such support from his corps as Roume. ${ }^{3}$ And yet he reached the most prestigious and powerful post in the Empire, the governorship of Algeria. In twenty years, from Roume's governorship of French West Africa to Carde's, the colonial administration experienced a radical transformation in its recruitment. We posit this transformation reflects the empowerment of the Empire as a social space, or at least of its administration.

1 The Léonore database, produced by the French Ministry of Culture, records the list of all individuals induced in the Legion of Honor since 1802, and provides access to a various set of biographical information related to each individual: www2.culture.gouv.fr/documentation/leonore/recherche.htm. Ernest Roume, notice LH/2392/4.

2 Jules Carde, notice LH 19800035/60/7418.

3 In this article, we use corps to refer to the French concept of corps d'État. High civil servants are both part of an administration and of a corps d'État. The formal occupation and the affiliation to a corps d'État are not always correlated. The later and the transition from one corps to another determines one's career. The affiliation to a corps cannot be interpreted as a mere rank but can provide an individual with collective resources 
The article builds on the argument developed by Abbott (2005) about linked ecologies and argues that empires are the product of social entities to structure themselves - specifically, inside the colonial administration. This article presents a study of the career paths of French colonial governors between 1830 and 1960. We analyse the process of professionalisation of this emerging social entity with respect to other social entities within the imperial space (ecology) and the French metropolitan space. We call this process empowerment. Using data on the career of 637 colonial governors between 1830 and 1960, we examine how variations in the recruitment of these high civil servants actually reflected the evolution of autonomy this entity conquered. We rely on optimal matching technique to distinguish typical sequence models and identify ten common career trajectories that can be grouped in four main clusters. We show that the rise of the colonial cluster during the Interwar period corresponded to the peak of the administrative autonomy in the colonial space, which is consistent with the broader history of French colonisation. We argue that this autonomy comes from both professional and organisational logics.

To what extent can an Empire be autonomous from its metropolis? Raising this question about the French second colonial Empire may seem paradoxical given that, by definition, in a colonial empire, a metropolis dominates colonies. However, populations originating from the metropolis and living in the Empire - the colonisers - can form a distinct social space both from the metropolitan space and the people originating from the colonies, the colonised. They lived in separate places, and formed communities in main colonial cities. However, these communities pertained to colonial spaces. Their existence did not necessarily imply the existence of a social space at the level of the empire. How autonomous is the imperial ecology from the strictly metropolitan ecology? The literature in social sciences assesses autonomy from different perspectives. Cooper and Stoler (2012) have shown that civil rights were a systematic way of dealing with difference in empires. Anderson (2006) proposes a more sociological approach by showing that nationalist movements originated from the creole populations. Contrary to the first European wave of colonisation, in the vast majority of French colonies of the second French colonial Empire, European settlers, including French, were in very small numbers and originated from the metropolis (Etemad 2000).

To assess the relationship between colonies and the metropolis, one needs to focus on that population. Following Bourdieu (2015) and his field theory, the more the rules and representations in the Empire are different from those of the metropolis, the more autonomy the colonies benefited from. Different rules, however, can well originate from the metropolis and are often the consequence of its domination over its colonies. In this article, we build 
on a different perspective, considering the civil servants as central to the autonomy of the administration of the Empire. That administration, in turn, constituted the core of the Empire, a large share of the colonial economy depending on public investments and its consumption (Cogneau et al. 2018). The colonial administration was very powerful in the colonies because part of the intellectual production came from its ranks and it faced no real counter-power in the absence of a true political representation in the colonies (Merle 2004). This article questions the autonomy of the French colonial Empire through that of its senior civil administration, drawing analytical tools from the sociology of professions. We shall focus on the top of its hierarchy, for its members were the ones that circulated and gave an imperial character to the social space they were in. Colonial administrators were usually specialised in a group of colonies, and the lower ranks of the hierarchy were specific to a colony (as in the British Empire, Kirk-Greene 2000).

The remainder of the article is organised as follows. Section 2 describes the colonial administration and draws on the literature to explore professionalisation processes in colonial administrations. Section 3 reports data sources and the dataset construction, and the design of the research. Section 4 describes the careers of colonial governors and their evolution over time. Section 5 proposes a narrative explanation to the empowerment of governors and the administrative imperial ecology.

\section{Professionalisation processes in colonial administrations}

In this article, we argue that contrary to what the literature on metropolitan administrative elites asserts colonial positions were far more than a mean of climbing the ladder in the metropolitan administration (e.g., Charle 2006). A specific empowerment process took place within the senior civil service, in which the relationship with the metropolis played a crucial role. Our hypothesis is that the autonomy governors attained at one period is crucial to understand the autonomy of the Empire from the metropolis.

\subsection{French colonial administration and governors}

The second wave of French colonial expansion began with the seizure of Algiers in July 1830. The development of steam warships facilitated the pursuit and the expansion of the colonial policies in Sub-Saharan Africa and Indochina during the Second Empire. The protection of the trading posts and missionaries soon became a pretext to more expansionist policies. From the military conquest of Senegal began by Louis Faidherbe in 1854 to the annexation 
of Cochinchina in 1862, colonisation represented a land of opportunities for the military. Nevertheless, most of the elite showed nothing but indifference to the question of colonisation, in particular after the Mexican fiasco in 1861. Only after 1871, the colonial ideology spread among political elites, who looked for a way to wash the humiliation of the Franco-Prussian War. The rising of the Third Republic and the development of the colonial culture have been concomitant, and lead to the establishment of the civilising mission as the official ideology of the French colonial Empire in 1895. Colonies were seen as a chance to foster national unification, to regain former global stature, and propaganda began to be used to sway public opinion in favour of colonisation (Bouche 1991; Manceron 2005, 139-200; Blanchard et al. 2008). By 1900, France had already established a firm control over its twenty or so new colonies (see Annexe 1 in Chambru and Viallet-Thévenin 2019). Colonial related issues continued to represent a growing share of the metropolitan public space during the first half of the 20th century until the wave of decolonisation in the 1950s. By 1960, only French Somaliland retained a position of colonial governors. The colonial administration within the French Empire was made of two components - leaving aside Algeria, Morocco, and Tunisia that were settlement colonies and had a very specific role in the Empire and relationship with the metropolis (Rivet 2002). One component was in Paris with administrative units depending from three different ministries. These units were not very powerful, because of their dispersion, the lack of specialisation of their civil servants and finally, their weak resources in terms of both manpower and budgets (Cohen 1973). The second component was made of administrative units operating in the colonies, mainly in the capital cities. Their organisation changed across time, but from their creation to the independences, they were always under the authority of a colonial governor. Colonial governors represented the State in a given territory, which size could vary, but that was autonomous in its budget from the rest of the Empire. Colonial governors were major figures in the French Empire, and many former governors seated in the largest colonial firms' boards and in governmental commissions after their leave from the colonies. According to Steinmetz (2008), and many historical monographs, they had a great influence on the colonies' government. For instance, Coursier (1989), Hoisington (1995), Lorin (2004) and Michel (1989) clearly demonstrated how these individuals shaped the polities they governed. We intend to show the professional logics at play. We focus on colonial governors as representative of a larger group of senior colonial civil servants in the colonial administration.

Previous works have shown how, in the British and French colonial Empires, the colonial administration followed a professionalisation process specific to a colony or group of colonies. In the British Empire, the Indian Civil Service was created in 1858, the Colonial Administrative 
Service and the Sudan Political Service in 1895 (Kirk-Greene 2000). In the French Empire, graduates from the École coloniale established a gradual monopoly over the colonial service, in particular from 1920. ${ }^{4}$ Their career paths differentiated from those of the military officers that filled colonial postings at the beginning of the colonisation (Cohen 1973) and they sought their legitimacy from a specific knowledge of the colonies, both practical and scientific (Dimier 2004; Fredenucci 2003; Singaravélou 2008). They specialised early in their career in one group of colonies and rarely moved from one to another. Comparatively to colonial administrator postings, one reached a governorship only after a long career, twenty to twenty-five years on average. These postings also implied very frequent relations with the metropolitan administration and were potentially quite attractive to senior metropolitan civil servants because they were both relatively prestigious and well payed, hence the issue of the autonomy. Moreover, the Président $d u$ Conseil rather than the Colonial Office directly nominated governors. ${ }^{5}$ We claim that their previous careers give a measure of the autonomy and of the colonial administration's legitimacy to govern itself.

There is a great variety of monographs on colonial administration (Singaravélou 2008). These studies usually focused on a group in a very precise historical and geographical context (Hélénon 2011; Rezzi 2005). Scarce are those trying to embrace a whole geographical context or the dynamics of a group on a long period of time. This literature has been largely regenerated with works on colonial legislations (Merle 2004; Saada 2003) and others building on a comparative approach (El Mechat 2009; Steinmetz 2008). The most recent studies on the colonial Empire and its elites propose to study the colonial Empire through circulations rather than through its territories (Klein 2012; Laux et al. 2009). Following these studies, we consider the Empire as a whole, and their governors as a plausibly distinct group.

\subsection{Colonial administration as a social entity}

We propose to consider social groups as entities (Abbott 2016). Entities are areas of work over which occupational groups try to establish monopolies by using specialised knowledge. These entities are part of ecologies. Ligation refers to the boundary work made by entities both inside and between ecologies. That approach can be applied to the State, considered as an ecology of entities. Such a framework focuses on the relations between the entities and invites to analyse simultaneously the way entities are constituted or constitute themselves through

4 Established in 1889, the École coloniale provided training for future colonial administrators. In 1934, it took the name of École Nationale de la France d'Outre-Mer (hereafter ENFOM). For the sake of simplicity, we stick to the term École coloniale throughout the article.

5 The Office colonial is the predecessor of the Ministry for Colonies created in 1894. 
boundaries and the jurisdictions they establish. In that perspective, we consider the colonial administration as an ecology in the making, with governors as an entity inside that ecology. They do not exist as such over the entire period. We will consider the autonomy of colonial governors both from the other entities in the imperial ecology and from other linked ecologies such as the metropolitan administration, the political sphere and the private sector. Studies of professions in an international space show that many individuals going abroad return to their national space to benefit from their international experience (Dezalay and Garth 2002; Fourcade 2006). On the contrary, Georgakakis and Lassalle (2007) have shown that senior civil servants were making use of their belonging to the European or national bureaucracy to claim prestigious postings in the European Commission. Overall, these investigations show the importance of the metropolis as a space of reference to international and colonial professional groups.

The careers of a specific population are a powerful tool to assess its professionalisation (Abbott 1992). We build on the literature highlighting career paths, their emergence and the broader context in which those processes take place (Bühlmann 2008; Stovel and Savage 2006; Stovel, Savage and Bearman 2001). We draw from an approach based on the careers of individuals to explore the autonomy of the governors' entity. Abbott (2005) asserts that the historicality of a profession is made of the historicality of the individuals exercising it. More specifically, the careers of the members of a professional group reveal the historicality of their profession. The memory encoded in the careers is what makes the historicality of a profession. They contain the representations and past practices and experiences that individuals use in their actions. The steps in the career of an individual show the entities and ecologies to which he belongs to or to which he is linked to. Taken together, the careers of the governors show the ligations between the colonial administration and other entities and ecologies. We thus use careers to locate the boundaries of the group.

We need to adapt Abbott's concepts to an administrative context. We first propose considering the organisational dynamics that impede on or favour the autonomy of the group of governors. It means investigating the recruitment process and the way the organisation of the colonial administration influenced the careers of governors. Understanding why one group is favoured over another requires an insight on the perceptions of those who recruit its members - the higher hierarchy in an administrative context.

We further depart from Abbott's perspective in a second and more substantial way. The entity we are interested in, the corps of governors, has a legal existence that pre-exists and 
has nothing to do with its existence as a social entity. In the literature on professions, legal autonomy is often the result of a successful professionalisation. Furthermore, governors are defined by their position at the head of the colonial administration, another social entity. The autonomies of the two are interrelated. The corps of governors has no autonomy at the beginning of the period under scrutiny, and hence, nor the colonial administration, because the recruitment is only the result of power struggles within the ecologies dominating the imperial ecology or within entities outside the colonial administration.

We call empowerment the process leading to the autonomy of the governors' corps from other social entities. Initially, their entity is only defined by the tasks assumed by its members. The group does not have any common history — in the form of historicality — nor is capable of any kind of collective action. It lacks an esprit de corps. What we call empowerment is the process leading to a social consistency of the entity. In this article, we use careers to assess this process. But in this particular case, the empowerment has two features. Because the governors have in common their governing position at the head of colonial administrations, one can also look at the empowerment process from the point of view of the whole administration. The empowerment of the colonial administration is effective if the governors come from its ranks. This constitutes a second level of empowerment. Though the colonial administration will only be relatively autonomous from the political sphere that retains the nomination power, be it from a pool of senior civil servants drawn from the colonial administration. This two-storey process is thus defined by a common career of the governors, and a common career in the colonial administration.

\section{Data and research design}

The individual-level data are from Chambru and Viallet-Thévenin (2019). In this paper, we collect detailed biographical data on the socio-economic background and the professional careers of every individual appointed at least once as colonial governor between 1830 and 1960. ${ }^{6}$ This data set includes information on 637 colonial governors and covers five colonial federations, 18 colonies and five protectorates. ${ }^{7}$

6 Colonies conquered during the first wave of French expansion prior to the nineteenth century are not included in the data set. Compared to the data set used in Chambru and Viallet-Thévenin (2019), we extend it to include individuals that hold a position in Morocco, Syria and Lebanon, and Tunisia.

7 Colonial federations: Algeria, Indochina, French East Africa, French West Africa and Madagascar. Colonies: Annam, Cambodia, Cochinchina, Laos, Tonkin, French Somaliland, French Congo, Oubangui-Chari, Tchad, Dahomey, French Soudan, French Guinea, French Upper Volta, Ivory Coast, Mauritania, Niger and Senegal. Protectorates: Cameroon, Morocco, Syria and Lebanon, Togo and Tunisia. In Table 5, we show that they were no sharp differences in terms of recruitment across these colonies, except for colonies in North Africa where the 
The historiography assumed that most colonial governors were coming from the École coloniale, a school created in 1889, and aiming at educating French colonial administrators (Cohen 1973). We began our collection by using the biographical dictionary of their alumni. The dictionary provides information about each step of alumni career paths including such pieces of information as their place and date of birth and death. The dictionary only provided us with information on 150 individuals, or 23.6 per cent of the population of governors (Table 1). We then turned to the Léonore database, produced by the French Ministry of Culture, and which records the list of all individuals induced in the Legion of Honor since 1802. ${ }^{8}$ People seeking the decoration assembled their professional records and sent it to the selection committee. These records display basic information needed to identify the individual together with the actions deserving the medal. Among other things, a resume, a birth certificate and an employment (military and civil service) record are often included. We further supplement this source with information derived from administrative career records from the Archives Nationales d'Outre Mer (ANOM), biographical databases of French parliamentarians, and various other sources (Table 1). ${ }^{9}$ If information was not consistent across sources, we always favour administrative records over other sources.

For each colonial governor, we assemble information on each stage of their professional careers preceding their appointment as colonial governor. At each stage, we collect five pieces of information on the position: the year of start, the year of end, the geographical location, the organisation, and the occupation. To analyse the career pattern of colonial governors, we decide to focus on the organisation variable, which provides information on the nature of the structure for which the individual worked. It has the advantage of being more homogeneous and easily comparable than the occupation variable. ${ }^{10}$

In Online Appendix A.1, we provide the full list of possible categories for the position and the organisation variables. In Table 2, we provide an example of our coding strategy using the

proximity with the metropolis and the status of Algeria altered the general pattern.

8 The decoration was created by Napoleon to honour the bravest officers and later extended to civilians, and was equivalent to the Most Excellent Order of the British Empire.

9 Base de données des députés français depuis 1789: www2.assemblee-nationale.fr/sycomore/recherche. Base de données des anciens sénateurs de la Troisième République: www.senat.fr/senateurs-3eme-republique/index. html.

10 We recoded every occupation into a new variable, denoted position, to reflect the type of position. The different categories are directly inspired from the rank system of the French Army and the French civil service system. For instance, individuals engaged in the Army could be either 'soldier', 'sub-officer', 'junior officer', 'senior officer', or 'general officer'. This variable is, therefore, disparate and comparing military with civil servant can make little sense. The first two categories (year of start and year of end) are relatively straightforward and do not require further explanation. The geographical location includes both the region (colony or country) and the country (colonial federation or country) where the individual worked. 
career of Pierre Pasquier. ${ }^{11}$ It should be noted that if information was missing at one stage of the career, the individual was included in our sample nevertheless, and the variables coded as missing. We additionally trim each observation on the left at the age of 18 . We could not retrieve any information for 24 individuals, so the process resulted in the creation of 613 sequences consisting of up to 48 consecutive annual statuses. ${ }^{12}$ It should be further noted that most sequences are coded as missing for few years between age of 18 and 25 because individuals did not work yet but completed their higher education training (Figure 2).

To analyse the sequences, we use the TraMineR package developed by Gabadinho et al. (2011). Abbott (1995) defines sequences as ordered lists of elements, which can be grouped together using optimal matching (OM) algorithms. We first compute pairwise dissimilarities between our sequences, before performing a dendrogram (hierarchical cluster) analysis to determine the optimal number of clusters (Figure 1). ${ }^{13}$ We then add a grouping variable to each observation and plot the distribution of sequences by cluster to identify patterns in our data and highlight the different professional careers that preceded an appointment as colonial governor. ${ }^{14}$

To interpret the career dynamics, we use in-depth study of the career records of governors. These records contain their yearly marks and assessments from their superiors, driving directly their careers. We use them to understand the practices and know-how valued in the colonial administration, and what processes lead to the emergence of patterns in the governors' careers.

\section{The variety of careers}

Based on indications provided by pairwise comparison and hierarchical clustering (Figure 1), we split our data set in 10 clusters to analyse the evolution of career of governors. Overall, three main distinct patterns emerged (Figure 2). Career paths associated with a professional activity in the metropolitan space include three distinct groups. Another three groups can be associated

11 These categories does not constitute, per se, a system that show a general ordinal level. However, some categories have clearly higher hierarchical level than others. Pierre Pasquier was governor of Annam from 1921 to 1926, and then governor-general of Indochina from 1928 to 1934. Pierre Pasquier, notice LH $19800035 / 308 / 41518$.

12 Information was too incomplete for another 16 individuals, which are grouped in a cluster that will not be analysed in the remaining section of the paper (Figure 2, cluster X). Dropping these individuals and repeating the analysis with only nine cluster does not alter the results.

13 In OM, the distance between sequences is measured as the minimum number of operations required to generate identical sequences.

14 We kept missing values and coded them as a state. All sequences were aligned on age. We normalised all distances when computing pairwise dissimilarities. We relied on the Ward's hierarchical clustering method to create our clusters. 
with military careers. Three more groups correspond to careers in the colonial administration. Finally, the last cluster (cluster X) includes governors with parsimonious information on their career, which prevent us to attribute them to any other group. Table 3 contains various groupspecific descriptive statistics that enable us to draw clear distinction between them.

\subsection{Metropolitan careers (I, VIII, and IX)}

Individuals include in these clusters are gathered in some of the smallest and least homogeneous groups. They share a metropolitan career, a relatively late departure for the colonies, and a low rate of acting position as governors.

\section{Politicians - I}

The 12 individuals of the first cluster spent much of their career holding electoral offices. They also spent time in the private sector and in the administration, exclusively in the central administration. They did not have the successful careers of the individuals from cluster IX in the administration, only two of them having held a senior management position. They went to the colonies at 41 on average, which is the latest age across all groups. As many as three-fourth of them reached the position of governor-general during their career. Born in 1833, Paul Bert began his career as a university professor, after no less than three PhD. After a brilliant career leading him to the Academy of Sciences, he was a deputy from 1872 to 1886 with a one-year interruption as minister for education. In 1886, at age 53, he was appointed general-governor for Indochina.

\section{Metropolitan civil servants - VIII}

The 67 individuals in this cluster spent their whole career in the metropolitan administration before their nomination as governors in the colonies at 49 , on average. Their careers mostly took place in the central administration (88 per cent). A large proportion of them reached prestigious positions, such as that of préfet (42 per cent) or senior management positions in the central administration (59 per cent). Most of them managed to secure permanent position as governors within their careers (92 per cent). Gaston Cusin became a customs officer by familial tradition. Born in 1903, his union activities gave him the opportunity to advise ministers from 1936 to 1939 as deputy chief of staff to the Minister for Public Finances and chief of staff of the Minister for Public Works. During this period, he organised the help to the Spanish Republicans. Later during the war, he organised smugglers' networks helping Free French Forces (Forces françaises libres) and took formal responsibilities in that organisation. In the 
aftermath of the war, he became a high civil servant at the Minister for Economy. In 1956, he was appointed high commissioner for French West Africa for two years.

\section{Private sector and metropolitan administration - IX}

Cluster IX comprises 37 individuals originating mostly from the private sector, but who also spent some time in the central metropolitan administration. Similarly, to other clusters from the metropolis, they almost all manage to have a permanent position in their career (92 per cent). Noticeably, they have the shorter time lapse between their first departure to the colonies and their first appointment as governors. Robert de Caix de Saint-Aymour was born in Paris the son of historian and archaeologist, he became journalist in 1893 after graduating from the École libre des sciences politiques. He soon travelled across North-America and then Algeria, Morocco and Tunisia, and later Indochina, Korean and China (1894-1904) to cover news and write stories on colonisation. An active member of the Parti colonial, he continued work as journalist and published on colonial-related topics until he joined the parliamentary committee Comité d'action française en Syrie in 1916. Secretary-general of the new protectorate of Syria and Lebanon in 1919, he was is appointed governor in 1922 at 53.

\subsection{Military careers (II, VI, and VII)}

Individuals include in these three clusters are gathered in some of the most homogeneous groups and differ only in where and how much time they spent in the Army.

\section{Metropolitan and successful commissioned officers - II}

The second cluster gathers 78 individuals. They have the longest careers in the population, spent almost exclusively in the armed forces, with sometimes a few years spent in the local colonial administration. They benefited from an early start (20 year old for their first commission), often after a military school (74 per cent) and almost 82 per cent rose to the rank of general or admiral. They experienced a career in the metropolis, had their first experience in the colonies, on average, at 31 and reach the position of governor at 54 , the latest of all groups. Born in Paris the son of an admiral, Victor Duperré entered the Navy as a ship's boy in 1840 at the age of 15. He received his first commission in 1846 as a graduate of the naval academy and commanded his first ship, a frigate, in 1855. He became the aide de camp of the Minister for the Navy and then his chief of staff, reaching the rank of captain. He subsequently commanded two navy outposts and became the chief of staff of the minister, and a rear admiral. He was commissioned governor of Cochinchina at 50 in 1875. 


\section{Career commissioned officers between the colonial and metropolitan armed forces - VI}

Cluster VI comprises 65 individuals. A mere 40 per cent reached the rank of general or admiral, even if 52 per cent of them graduated from a military school. Regarding geographical trajectories, the group is less homogeneous than the cluster II: a quarter spent the entirety of their career in the metropolis; a third spent much time in campaigns abroad, but not in the colonial empire; and the rest (approximately 40 per cent) share their time between the metropolis and the colonies. Henri Canard arrived in Senegal with a cavalry company as a soldier. He was the son of a boatswain, born in 1824 in Rocroy in the Ardennes. From 1847 to 1870 he climbed the hierarchy, becoming a commissioned officer in 1855 and taking command of the cavalry in Senegal in 1863. He took part in many operations asserting the French rule over the territory. In 1870, he was appointed chef d'arrondissement, given the task of administrating a small portion of Senegal, because of his knowledge of the country. He remained in the army during this period and reached the rank of colonel. He was later appointed governor of Senegal in 1881 thanks to the constant support of his superiors (the previous governors). Because of his lack of supports in the metropolitan administration, he was replaced in 1882 by René Servatius (Group IV).

\section{Career officers retrained as colonial administrators - VII}

Cluster VII comprises 49 individuals. They began their careers in the armed forces, but retrained as colonial administrators after seven or eight years on average. They had less successful career in the armed forces than their counterparts from cluster VI: only 27 per cent graduated from a military school and about one-third were commissioned officer. They decided to embrace the colonial career sooner than their peers did as they retrained as colonial administrators on average after seven or eight years in the army. In the colonial administration, they enjoyed careers close to those of cluster IV, centred on the local colonial administration. In the end, the final stages of their careers look a like those of cluster VI: they both reached the position of governor at a relatively young age (43-4 years old) and they share a similar distribution between the highest position attained. Henri Danel was the son of a wine merchant born in Béthune in the North of France. He graduated from École Navale (French Naval Academy) in 1869. He served on many vessels during 15 years before taking an exam and becoming an inspector in the nascent colonial administration. After 8 years of service, , he served as governor for Cochinchina (a part of Indochina) from 1892 to 1895, and then in La Réunion and French Guyana until 1898. He later died in service during an inspection mission in Senegal at 50 . 


\subsection{Colonial careers (III, IV, and V)}

The three clusters with careers centred on colonial administration differ according to the time spent in the local and central administrations.

\section{Local colonial administrators - III}

Cluster III comprises 124 individuals whose careers were centred on local colonial positions. They spent all their careers in the colonies, in which they arrived at an early age (24 years old), after graduating from the École coloniale in half cases. Overall, about 32 per cent of them began as clerk, the lowest rank in the colonial administration. They usually became governors after long career (25 years), but could not secure permanent position in almost half cases (45 per cent), the highest rate across all clusters. Only 11 per cent ever became governor-general, the lowest rate across all clusters. ${ }^{15}$ Frederic Estèbe was born in Argentina in 1863. He was a schoolteacher for six years in France, before being sent to Madagascar as a schoolteacher. He rose in the ranks of the colonial administration in Madagascar, being given command over larger and larger administrative units until he became mayor of the capital city and then supervised the province around it. In 1911, he was appointed governor for Oubangui-Chari.

\section{Successful local colonial administrators - IV}

Similarly to cluster III, half of the 126 individuals in cluster IV graduated from the École coloniale. They arrived in the colonies at 25 and spent most of their career in local positions in the colonial administration. Contrary to the individuals from cluster III, only 17 per cent began its career as a clerk and many experienced positions in the central colonial administration. Overall, they had a far more successful career than their counterparts did from cluster III: they became governors on average after 18 years of careers and 82 per cent secured at least one permanent position as governor. Camille Bailly was born in 1907 in Amiens in Somme. After a bachelor degree in law and a master's degree in political economy, he graduated from École coloniale. He began his career in the local administration in Indochina. In 1940 he became chief of staff of the governor-general for Indochina in Saigon. He subsequently spent two years in Cambodia as chief of staff to the governor. He then took the head of a department at the general governorate for two years. In 1948, he left Indochina never to return. After one year as a local administrator in Ivory Coast, he became deputy governor for Senegal. He was then appointed successively governor for Senegal, Ivory Coast, and French Sudan.

15 Among the three clusters in the colonial administration, they have the lowest entropy (0.27). 


\section{Colonial administrators in central administration - V}

Cluster V comprises 39 individuals. They spent most of their career in the central colonial administration with a few years spent in the metropolitan administration and the local colonial administration. A substantial proportion of them went through staff positions (44 per cent), and 41 per cent were secretary-general before becoming governors. Armand Annet was born in Paris in 1888. He was sent to the colonies in 1911 as a clerk after his military service and a baccalauréat. He soon joined the staff of the general governor for French West Africa in 1914, before campaigning in Cameroon as a commissioned officer. In 1917, he was chief of staff for the governor for Moyen-Congo. He then held various staff positions in French West Africa until becoming a governor in 1935 for French Somaliland.

The ten clusters differ in terms of professionalisation and time spent in the colonies. Some groups follow very established career paths such as those of metropolitan senior civil servants (VIII) or military officers (II and VI). Some clusters are in between a colonial career and an established career path in the institutions pre-existing to the colonial administration, having experienced a professional bifurcation (cluster VII). Finally, clusters III, IV, and V show individuals whose careers were centred on the colonial administration but showing significant differences in their structure and development.

\section{The empowerment of governors}

Three processes participate of the progressive empowerment of the governors. Their interplay can explain the rise of colonial administrators in the ranks of governors and their late decrease. The institutional empowerment of the colonial administration, the emergence of a jurisdiction for colonial administrators and the evolution of their competitors' jurisdictions. The following section presents a general narrative of the recruitment process in three phases. It seeks to explain the variations in the prevalence of the groups identified in Section 4. It is noteworthy that we do not find any effect of governors' socio-economic origin, measured with father's occupation, on the probabilities to follow one or another career trajectories. ${ }^{16}$

\subsection{Institutional empowerment and demilitarisation}

During a first period, the imperial ecology was strongly ligated to the metropolitan ecology and the governor's entity depended completely on processes occurring in the metropolitan

16 The average HISCAM score per cluster ranges between 76.2 and 79.1, even though the variability of socioeconomic origins among governors is much higher (Chambru and Viallet-Thévenin 2019, pp. 72-4). 
ecology. The processes affecting the governors' entity originate from organisational logics.

The corps of colonial governors was ruled in 1860 by the ordonnances organiques (organic Acts) of the 21 August 1825, 9 February 1833, and 7 September 1840 concerning French Antilla, La Réunion and Senegal, expanded to the new colonies. The Président du Conseil (head of the executive branch) nominated governors: these nominations followed no formal process until their institutionalisation in the 1900s. At the beginning of the French second colonisation's phase governors were thus mostly military officers (Figure 2, clusters II and VI). The colonial administration departments in the metropolitan administration operated under the umbrella of the Ministry for Navy, with no proper autonomy. Colonial civil servants served under a military status and governors were mainly officers drawn from the colonial units present at the time in the colony. The governors did not constitute a social entity different from the corps of officers from the Army or the Navy. A vast majority of colonial administrators (senior civil servants ranking below governor) were also military officers. The post of governor was not considered as a step in a colonial administrative career but rather as a short-term secondment from the Army or the Navy.

Two former governors of Senegal, career officers but more invested in the colonial administration than their predecessors became the advocates of a demilitarisation of the colonial administration. They made use of the dominant positions they occupied later in the metropolitan space. Louis Faidherbe was a commissioned officer in the Armée d'Afrique (occupying Algeria) and a governor of Senegal between 1854 and 1861 and again in 1863-1865. He became général de division, the highest rank in the French army at the time, and late a senator. Jean Jauréguiberry was a Navy officer and made a great number of stays in the colonies during his career before governing Senegal from 1861 to 1863 . He later became an admiral and the Minister for Navy and the colonies (1879-1880 and then 1882-1883). Both of them considered that governors coming from the armed forces were not qualified and advised the Minister for Navy not to nominate randomly and for personal convenience officers that would stay a year or two. In 1880, Jauréguiberry put an end to the gouvernement des amiraux of Cochinchina by nominating civil governors and favouring the recruitment of civil colonial administrators. The concerns for governors' qualifications came with a concern for autonomy from the subsecretary of State for colonies - under the authority of the Ministry for Navy and the colonies until 1894. The recruitment of a dedicated civil staff was a way to ensure its autonomy from the Ministry for Navy.

During the 1880s, the empire expanded, with the creation of seven new colonies in Indochina 
and Africa, and one confederation in Equatorial Africa. At that time, administrative units were created out of territories previously under military rule. The colonial conquests being under way, and resistance far from extinguished, the navy concentrated much power in the Empire. The demilitarisation of the administration was implemented by the Department of Colonies and sustained by essayists and publicists to empower the colonial administration in its confrontations with the military hierarchy (d'Andurain 2017). Demilitarising the Empire administration was perceived as a way to shift from a policy of conquest to a policy of exploitation. The share of governors who made their whole career in the navy or in the army before getting a governor's position decreased rapidly (Figure 3). The better resilience of the individuals from cluster VII can be explained by their earlier arrival in the colonies and thus the knowledge of the colonies and ties they had to the colonial administration. In the absence of a proper colonial administration, metropolitan high civil servants were thus given the opportunity to rule colonies; hence the sudden rise in the share of the careers spent in metropolitan administration from 1880 (cluster VIII).

Metropolitan senior civil servants were thus progressively favoured over metropolitan officers; the colonial administration differentiated itself from the armed forces. During that period, the Department for Colonies was still not autonomous and the colonial administration in the colonies depended heavily from the metropolitan administration (cluster VIII and partially IX). The governors' jurisdiction was not well established, and their attributions were still changing, in competition with the Ministry for Navy and the officers commanding the armed forces in the colonies. During this first phase, a differentiation process occurred, separating colonial governors from the commanding officers of the colonial Army and the Navy. It relied on the emergence of a first boundary separating military and civil posts and careers. The empowerment process of the colonial administration from the Army and the Navy is rooted in organisational logics, i.e. the empowerment of the Department for Colonies from the Ministry for Navy. These processes took place in the metropolitan ecology; the imperial ecology as such was merely emerging.

\subsection{Emergence of a proper jurisdiction}

Focusing on the recruitment process helps to understand the empowerment of the governors' corps. Until the First World War, the metropolitan administration provided over one third of all colonial governors. The creation of a specific recruiting process for the colonial administration only dates back from 1887 (Cohen 1973). That transformation was contemporaneous to the establishment of the Ministry of Colonies in 1894, after ten years of unsuccessful attempts. 
The creation of federations and the position of governor-general reinforced substantially the administration in the colonies. Federations were created because of the need expressed to coordinate their development, politically and economically.

Governors-general gained a substantial autonomy, in particular on issues such as budgets and recruitment policies. Governors-general became involved in the nomination processes; and nominated people they knew (and trusted!). A promotion system was implemented, with the direct superior and the governor in charge of the colony marking every senior civil servant every six months. The governor in charge of the colony was the only one who could propose someone to a higher rank or post; the minister having only a veto power. Recommendation letters were sent to the ministry to accelerate a promotion or ask for a change of colony, mostly from Parliamentarians in the metropolis, but do not seem to have had a substantial effect. The Minister for Colonies ultimately chose governors. However, the exchanges of letters between governors-general and the ministry show the minister chose them after a careful selection by the governor-general among the ranks of his senior civil servants. The nominations rarely differed from the propositions. Administrators in chief, the most senior rank in the corps of colonial administrators were subject to very detailed notations, before being given access to the corps of colonial governors. Progressively, the attention broadened towards the nomination of general secretaries, second in command in a colony. These positions came to be considered as a final step in a career leading to a governorship. Progressively, criteria emerged, putting aside military officers without administrative experience and metropolitan administrators, with no experience of the colonies. The judgements exercised in the marking process tell us about the ideal model of colonial governor that emerged progressively. A jurisdiction arose from the emerging boundaries erected by the successive judgements and nominations.

In that second phase, part of the group of colonial officers progressively merged with the colonial administration. While pursuing a career in the Army, they took administrative postings with increasing responsibilities. Some of them transferred after a few years in the colonial administration, reaching senior postings (clutter VII). The final steps of a career in the Army depended much on one's social capital, a career in the colonial administration was an interesting alternative for the ones with the more modest origins. A porous boundary emerged between the colonial Army and the colonial administration. Their knowledge of the colonies was valued, as well as the prestige that their career could reflect on the colonial administration.

I am not dissimulating the deficiencies of $\mathrm{M}$. Fourn administrative training. But he compensates those with a perfect knowledge of the country, that no other would 
acquire before a long period of time, lost to the urgent handling of the colony. ${ }^{17}$

Magnificent commanding officer that wrote a beautiful page in French West Africa and did eminently his duty during the war. High merit administrator fulfilling with a rare authority the function of commissioner. ${ }^{18}$

Another boundary thus emerged between metropolitan and colonial administrative careers, through the recruitment of individuals with an experience in the colonies. The high civil servants coming from the metropolitan administration did not last long and were progressively replaced from the mid-1890s onward by individuals with an experience in the management of the colonies (clusters III, IV V, and VII). Moreover, during this period, the colonial administration became more and more common as a career leading to ruling a colony. The posts of general secretary (closely looked at by the hierarchy because considered as a governorto-be), and acting governor became the last steps leading to a governor posting; it became more and more difficult to be nominated directly as a governor: the main exceptions being the general governorship of Indochina and Algeria that retained a certain political character.

The comments on the bi-annual evaluation sheets valued three different set of skills. Leadership abilities were highly regarded. A warlike vocabulary is often used (commanding capacity, chief, etc.) to describe the attitude/demeanour of the senior civil servants. In particular, this commanding ability has much to do with how colonial administrators behave themselves with the colonised. Some comments in the evaluation sheets only mentioned those skills. In a context where the colonisers were less than 0.1 per cent of the total population and have to rely heavily on the colonised, it was expected from the governors to compensate with leadership qualities. ${ }^{19}$

One of the most beautiful character I have ever known: M. Troadec is made of a calm block, a perfect equilibrium. He has both the taste and the sense of responsibilities. He is a Chief.

17 Evaluation of Gaston Fourn by the Governor-general for French West Africa, when Fourn was a acting governor for Dahomey. Fourn was a Saint-Cyr graduate in 1891, on secondment from the Army in the geographical service in 1896 and ultimately since 1901 in the colonial administration. Section B in the Online Appendix for the French translation of every quote. Fourn: quote 1. ANOM, EE/II/965/1, dossier Gaston Fourn.

18 Nicolas Gaden, battalion commander in the colonial infantry, on secondment in the colonial administration at the time (1917); acting as the commissioner for the governor in Mauritania. Gaden: quote 2. ANOM, EE/II/974/1, dossier Nicolas Gaden.

19 Legal coercion and forced labour were also important tools to ensure domination over the local population. 
He is asserting himself as a complete civil servant, with all the qualities of a chief. 20

M. Rey handled Senegal with a command that imposed itself upon everyone in his colony. Systematic, accurate and voluntary, his personality makes him a Chief, and an African Chief by his rich and orderly knowledge that went deep in the understanding of the things and people of this country. ${ }^{21}$

What does it mean to be a 'Chief'? Governors and colonial administrators are supposed to personify the presence of the metropolis. It goes with a symbolic apparatus ranging from the white uniform, the residence, the ceremonies dramatising the power of the metropolis and centred on the governor. The governor is thus supposed to possess a whole set of social skills associated with a high social status at the turn of the 20th century: elegance, courtesy, conversation, and much authority.

Aside from their manners, senior colonial civil servants are judged upon two distinct fields of expertise: a knowledge of administrative procedures, and a knowledge of 'the indigenous people'. Those shape the jurisdiction of senior colonial civil servants and draw boundaries with the metropolitan groups and the colonial Army. What is expected is a practical knowledge of the colonised, helping the colonial administration achieve its tasks. Marcel Marchesson, born in 1879 entered the colonial administration in 1905 as a clerk. He reached the rank of colonial administrator in 1916, becoming a governor in 1931. Until then, he always held regional commands as a commandant de cercle (district officer). In 1913, his governor noted:

He will make a fine administrator when he will have improved his administrative general culture by serving some more time in a subaltern position in a large region, or even better, in the offices of the governor. ${ }^{22}$

Jules Brévié symbolises the most successful colonial career one could achieve; governor in 1922 of Niger, he subsequently governed the Ivory Coast, and became governor-general for French West Africa and finally Indochina. His notation in 1921, while governing the Ivory Coast, expressed a high command of the three set of skills expected from governors:

20 René Troadec graduated from the École coloniale in 1934.In 1955, he was secretary general for French Somaliland. Troadec: quotes 3 and 4. ANOM, EE/II/4108, dossier René Troadec.

21 The General governor for French West Africa in 1941 about Georges Rey. Born in 1897, Rey graduated from Saint-Cyr, entered the colonial administration in 1925 and became a governor in 1940. Rey: quote 5. ANOM, EE/II/4108, dossier Georges Rey.

22 Marchesson: quote 6. ANOM, Gouvernement G1 AEF C/1209/MARCHESSON. 
Beautiful administrative training, profound knowledge of indigenous milieus, general culture, upright in his judgement, and high moral qualities. ${ }^{23}$

On the contrary, the appreciations are rude towards those considered not industrious enough and critical of the colonial system; a certain loyalty is expected. Many commentaries have to do with social skills, all the more important for colonial civil servants working in central directorates. This particularly true for civil servants working at the finances' directorate and the political affairs' directorate could possibly reach the rank of governor without ever being a district officer. When an administrator oversees a regional command, the notations mainly consider his achievements. Those are mainly judged, until 1945, from the point of view of the fiscal policy and the political stability of the region. The ideal candidate is a colonial civil servant with an experience in both central administration and in local administration, as a district officer, respectively ensuring the quality of his administrative knowledge and his knowledge of the colonised.

He mainly served as an advisor and served only 9 months in a district. His colonised administrative knowledge is and can only be limited. ${ }^{24}$

But he has 30 years long political career. He was a councilman, the mayor of Amiens, conseiller general and then Member of Parliament. He remained very political, and I sincerely believe that in a colony such as Senegal, the hour has not yet come to agitate the issues that we are preoccupied in in France. One should give him the command of one of the old colonies which functioning is more or less close to that of the metropolis. ${ }^{25}$

The attributes appearing in the evaluations are the product of the career of their producers and exert a filter on the promotions and nominations to sensible postings. Careers in the colonial administration progressively differentiated between the central and local administrations, hence the later rise of governors originating from clusters III and IV. During this period, colonial administrators shared these prestigious positions with military officers and metropolitan civil servants, but also politicians and people coming from the private sector.

23 Brevié: quote 7.

24 Joseph Bride who started his career as a clerk, the lowest administrative rank, in Indochina in 1895, never became a permanent governor. Bride: quote 8. ANOM, EE/II/1772/3, dossier Joseph Bride.

25 Comment of governor general Van Vollenhoven, about Fernand Lévecque, governor of Senegal. Van Vollenhoven does not mention his experience in the colonial administration. After his political career, Lévecque, was nominated deputy director for the customs in Indochina in 1900, and then governor for Annam, French India, Guyana, and only then Senegal, in 1917. Lévecque: quote 9. ANOM, EE/II/965/1, dossier Fernand Lévecque. 
Colonial administrators progressively established a quasi-monopoly over the nomination of governors from 1920 to 1940: it reached at its peak 85 per cent of all governors (clusters III, IV, and $\mathrm{V})$. It became more and more difficult to make a conversion in the middle of one's career. The boundary work was progressively taken in charge by members of the corps whereas at the principle, it was mainly the product of external -- organisational - forces. Mentions of an esprit de corps appear in the career files, especially about graduates from the École coloniale, or when metropolitan civil servants are nominated in the colonial administration. Yet, during this period, it was harder for a colonial administrator to reach the rank of governor-general than it had been between 1880 and 1920. The segmentation inside the colonial administration was mirrored in the governors' career paths, centred on central administration positions (cluster V) or local positions (clusters III and IV). At that point, the colonial administration had reached a high autonomy and was headed by people coming from its ranks. The colonial administrators had established a strong jurisdiction on the government of colonies.

The relative autonomy that the colonial higher administration reached in the 1920s cannot solely be explained by the emergence of boundaries around its jurisdiction. The nomination of governors being in the hands of the head of State, the Président $d u$ Conseil, the recommendations of the governors-general could well be ignored. Metropolitan groups of senior civil servants - part of powerful groups that structured the careers: the grands corps - wielded a considerable power over nominations in the first decades of the 20th century (Charle 2006). In France, the administration is divided into corps: legal entities that determine one's career. Some civil servants are part of the so called grands corps, that give access to the highest positions in the State's administration. Concentrated in the Empire, the colonial administrator's corps did not attain such a reputation and lacked the social prestige of other corps (Cohen 1973). The opportunities given to three corps shed a different light on the governor's corps; in the 1920s, the private sector opened up to senior civil servants and offered an alternative to a career in the colonies. Members of the Inspection Générale des Finances (IGF), one of the most prestigious grands corps found very attractive executive positions in the private sector as soon as the 1880s. Members of the préfectorale, senior representatives of the State at a local level, had many positions at hand in the 1920s. Finally, senior army officers got access after the First World War to executive positions in the private sector and were characterised during the Interwar Years by the highest rate of reconversion to the private sector of the whole public sector (Charle 1987). Successful metropolitan civil servants had other opportunities, both more prestigious and lucrative.

The empowerment process of the colonial administration can thus be understood by the 
emergence of a jurisdiction for colonial governors in the imperial ecology. One needs also to look at the ligations between the imperial and the metropolitan ecologies. These ligations are the product of two processes: the circulation of metropolitan civil servants and Army officers between the spaces and the perception of the Empire from the metropolitan administration. During this second period, the idea that the Empire had to be developed along lines different from the metropolis gained support (Conklin 1997). The success of that idea helped legitimize the colonial administration and reinforce its jurisdiction over the Empire. The circulations of metropolitan civil servants decreased because of the opportunities they had in the metropolitan ecology. Finally, the circulations of colonial civil servants to the metropolitan ecology were extremely limited, or forbidden, by their legal status and the idiosyncratic character of the knowledge they used in the colonies, as considered from the metropolis. The success of the closure of their jurisdiction in the empire closed them the metropolitan space. No imperial career, as successful as it might be, ended in the metropolitan ecology.

\subsection{Segmentation and partial loss of autonomy}

The situation changed from the beginning of the Second World War onward. During this last period, colonial administrators lost ground up to the point in 1960 when they represented only 50 per cent of all colonial governors. The Second World War brought opposition to colonisers. The perspective of decolonisation and the political changes in the Empire in the aftermath of the war prompted the Ministry for Colonies to nominate senior metropolitan civil servants and Army officers that it could trust (clusters II and VIII). Many colonial administrators reaching the rank of governor in that period had proven their allegiance to de Gaulle by engaging in the Résistance. Confronted with social movements and social demands for institutional and legal changes (Cooper and Stoler 1997), the French government nominated governorsgeneral politically close to the majority party. Governors-general were considered as its direct envoys, conducting governmental policies, whereas they used to be more autonomous. This recruitment policy segmented the corps of colonial governors, with a specialisation of those with a previous career in the colonial administration in local affairs.

The change of tasks and the relative convergence of labour and economic policies with the metropolis also legitimated a return of metropolitan senior civil servants. The relationships with the colonised and the legal framework converged-- although very slowly - towards the metropolitan model, and the economic development of the colonies was planned along similar lines as the metropolis. The colonial administration legitimacy drawn from their dealings 
with the colonised lost recognition. The proportion of colonial governors originating from the colonial administration began its decrease before the Second World War, which is consistent with changes observed in labour policies in the 1930s by Cooper (1996).

The nominations of former résistants was also a mean to reward them. After France liberation, many with little or no administrative experience were nominated as préfets, as a mean to politically control the liberated territories. As the political situation stabilised, former résistants were replaced by senior civil servants with administrative experience. Some of them were sent to take senior positions in the colonies.

I have to insist on the necessity to entrust this politically sensitive territory [Dahomey] to a governor with a previous knowledge of indigenous politics and minds. ${ }^{26}$

Some of them operated a very gradual transition, from managing a département in the metropolis, to managing one of the oldest colonies (conquered during the 18th century), converted into départements in 1946 to governing a colony. But past their first nomination, their careers were not easy in the colonial administration. At some point, René Petitbon was nominated as colonial inspector for French West Africa. In a note to the minister, the governorgeneral voiced his concerns about the nomination: 'I strongly believe I must inform you of the administration and the governor's reaction. They won't easily accept to be inspected by a foreigner to their corps' ${ }^{27}$ The governor-general wanted someone intimate with the functioning of the colony and most of all, someone originating from that administration.

Structurally, from 1946 onward, the number of colonial postings shrunk. The number of territories under colonial status shrunk with the independence of Lebanon and Syria, and the conversion of 'old colonies' conquered during the 18th century into départements, headed by metropolitan préfets. In addition, from 1945 onward, many colonial administrators operating in Indochina evacuated Asia and were incorporated in the colonial administration in the rest of the Empire. The competition for governors' posts became even fiercer. Hence the preferred recruitment of alumni of the École coloniale over people having held junior postings in the colonial administration (clusters III and IV over clusters V and VII). The École coloniale gained during this period a status comparable to the most prestigious French Grandes Écoles in the 1930s (Cohen 1973). Against the clerk climbing the ladder or metropolitan senior civil servants

26 The governor-general for French West Africa, writing about René Petitbon, former resistant and préfet from 1944 to 1948 and colonial governor from 1949 to 1962. Petitbon: quote 10. ANOM, EE/II/5450/PETITBON, dossier René Petitbon.

27 Petitbon: quote 11 . 
converted in the colonial administration, the graduates from the École coloniale could draw a legitimacy from the formal knowledge their training covered. They moreover formed a group that recognised and valued its own. The administrators with a career in the local colonial administration progressively lost their access to the governorship.

He is very knowledgeable in the ways of the indigenous people and the administration of our territories in Africa, whereas he seems ill prepared to the administration of our colonies with an elected body, and electoral struggles. ${ }^{28}$

Due to the decolonisation process, the government preferred to appoint trusted politicians (cluster I), high civil servants (cluster VIII), or individuals from the armed forces (clusters II and VI). Moreover, these metropolitans occupied the governor-general positions, with 40 to 71 per cent chances of becoming a governor-general compared to colonial governors (whose chances reached a mere 20 per cent for clusters IV and V. A hierarchical differentiation occurred, between the career paths leading to the position of governor and those leading to the position of governor-general. At the same time, colonial administrators were in a difficult position and lost their domination over the territories because of the emergence of engineers from technical services coming from the metropolis on one side and indigenous chiefs on the other (Dimier 2004). Those who reached the post of governor were the ones with a professional legitimacy drawn from their training at the École coloniale.

The story is thus twofold: the rise of colonial administrators, and thus a relative autonomy of the imperial ecology from 1920 to 1940, an empowerment process that goes on with the nomination of more and more graduates from the École coloniale. However, this autonomy is limited from 1940 onward by the recruitment of governors coming from the metropolis, reaching the rank of general governor-general more easily. The ligation of the imperial ecology with the metropolitan one is therefore determining in this last phase.

\section{Conclusion}

The empowerment of governors from the 1860 s to the 1930s is the product of a four step process. Boundaries are progressively erected with other social entities. Colonial governors are first isolated from the Navy through an organisational process that sees the Ministry

28 The general governor for West French Africa about Henri Lejeune in 1917. Lejeune was born in 1866, and began his career as a rédacteur at the Ministry for War, became a deputy administrator in Algeria in 1895, general secretary in 1908, and became a governor in 1917. Lejeune: quote 12. ANOM, EE/II/1089/6 et EE/II/3017/10, dossier Henri Lejeune. 
for Colonies take its independence. The emergence of a jurisdiction takes its roots in the creation of general governorship and the subsequent creation of recruitment categories specific to the colonial administration. The history of the autonomy of the colonial administration is as much the product of organizational logics as professional logics. The politicisation of colonies government from the 1930s on alters the autonomy and restricts its professionals to local governments. The ligation of the imperial ecology with the metropolitan one is therefore determining in this last phase.

The group of governors appear as an interface between entities ligated to or within the imperial ecology. They are a second order elite to the metropolitan administrative elite; their autonomy is under a constant threat from metropolitan groups, especially from grands corps.

British colonial governors enjoyed a comparable autonomy in Africa, the most comparable imperial space to the French colonial Empire, with 80 per cent of governors coming from the colonial administration in the 1940s (Kirk-Greene 1979). But the British colonial administration did not experience such a loss of autonomy as the French one. One can attribute that difference to the high status achieved by colonial administrators within the British public administration and possibly the incomparable wealth of British African colonies.

This paper explores the relationship of the colonial administration with other social spaces, but we must acknowledge for one substantial limit. We did not explore the autonomy of the colonial administration together from the economic sphere, mainly because our sources are administrative in nature. We know from other studies that many former governors seat at the board of colonial companies, and governors were under a constant pressure from the lobbying exerted by colonial firms (Viallet-Thévenin n.d.). 


\section{References}

Abbott, Andrew (1992). 'From Causes to Events: Notes on Narrative Positivism'. Sociological Methods E Research 20.4, pp. 428-455. DOI: 10.1177/0049124192020004002.

- (1995). 'Sequence Analysis: New Methods for Old Ideas'. Annual Review of Sociology 21.1, pp. 93-113. DOI: 10.1146/annurev.so.21.080195.000521.

- (2005). 'Linked Ecologies: States and Universities as Environments for Professions'. Sociological Theory 23.3, pp. 245-274. DOI: 10.1111/j.0735-2751.2005.00253.x.

- (2016). Processual Sociology. Chicago: University of Chicago Press, p. 336.

Anderson, Benedict (2006). Imagined Communities: Reflections on the Origin and Spread of Nationalism. London: Verso, p. 256.

d'Andurain, Julie (2017). Colonialisme ou imperialisme? Le parti colonial en pensée et en action. Paris: Hémisphères Éditions, p. 439.

Blanchard, Pascal, Sandrine Lemaire and Bancel Nicolas (2008). Culture coloniale. De la Révolution française à nos jours. Paris: Éditions du CNRS, p. 768.

Bouche, Denise (1991). Histoire de la colonisation française. Tome 2 : Flux et reflux 1815-1960. Paris: Fayard, p. 607.

Bourdieu, Pierre (2015). Sociologie générale. Volume 1. Cours au collège de France 1981-1983. Vol. 1. Paris: Seuil, p. 740.

Bühlmann, Felix (2008). 'The Corrosion of Career? Occupational Trajectories of Business Economists and Engineers in Switzerland'. European Sociological Review 24.5, pp. 601-616. DOI: $10.1093 /$ esr/jcn019.

Chambru, Cédric and Scott Viallet-Thévenin (2019). 'Mobilité sociale et Empire : Les gouverneurs coloniaux français entre 1830 et 1960'. Revue d'histoire moderne contemporaine 66.4, pp. 53-88. DOI: $10.3917 /$ rhmc.664.0053.

Charle, Christophe (1987). 'Le pantouflage en France (vers 1880-vers 1980)'. Annales. Économies, Sociétés, Civilisations 42.5, pp. 1115-1137. DOI: 10.3406/ahess.1987.283438.

- (2006). Les élites de la République. Paris: Fayard, p. 616.

Cogneau, Denis, Yannick Dupraz and Sandrine Mespé-Somps (2018). Fiscal Capacity and Dualism in Colonial States: The French Empire 1830-1962. Working Paper 27. Paris School of Economics.

Cohen, William B. (1973). Empereurs sans sceptre : histoire des administrateurs de la France d'outremer et de l'École coloniale. Paris: Éditions Berger-Levrault, p. 304.

Conklin, Alice L. (1997). A Mission to Civilize: The Republican Idea of Empire in France and West Africa, 1895-1930. Stanford: Stanford University Press, p. 384.

Cooper, Frederick (1996). Decolonization and African Society: The Labor Question in French and British Africa. Cambridge: Cambridge University Press, p. 677. DOI: 10.1017/CBO9780511584091.

Cooper, Frederick and Ann Laura Stoler (1997). Tensions of Empire Colonial Cultures in a Bourgeois World. Berkeley: University of California Press, p. 463.

- (2012). Repenser le colonialisme. Basingstoke: Palgrave Macmillan, p. 218.

Coursier, Alain (1989). Faidherbe, 1818-1889 : Du Sénégal à l'armée du Nord. Paris: Tallandier, p. 229.

Dezalay, Yves and Bryant G. Garth (2002). The Internationalization of Palace Wars: Lawyers, Economists, and the Contest to Transform Latin American States. Chicago: University of Chicago Press, p. 352.

Dimier, Valérie (2004). 'Le Commandant de Cercle: un « expert » en administration coloniale, un «spécialiste » de l'indigène ?' Revue d'Histoire des Sciences Humaines 10.1, pp. 39-57. DOI: 10.3917/rhsh.010.0039. 
El Mechat, Samia (2009). Les administrations coloniales XIXe-XXe siècles. Esquisse d'une histoire comparée. Rennes: Presses Universitaires de Rennes, p. 268.

Etemad, Bouda (2000). La possession du monde : Poids et mesures de la colonisation (XVIII ${ }^{e}-\mathrm{XX}^{e}$ siècles). Bruxelles: Édition Complexe, p. 352.

Fourcade, Marion (2006). 'The Construction of a Global Profession: The Transnationalization of Economics'. American Journal of Sociology 112.1, pp. 145-194. DOI: 10.1086/502693.

Fredenucci, Jean-Charles (2003). 'La brousse coloniale ou l'anti-bureau'. Revue française d'administration publique 108.4, pp. 603-615. DOI: 10.3917/rfap.108.0603.

Gabadinho, Alexis, Gilbert Ritschard, Nicolas Séverin Mueller and Matthias Studer (2011). 'Analyzing and Visualizing State Squences in $\mathrm{R}$ with TraMineR'. Journal of Statistical Software 40.4, pp. 1-37. DOI: 10.18637 /jss.v040.i04.

Georgakakis, Didier and Marine de Lassalle (2007). 'Genèse et structure d'un capital institutionnel européen. Les très hauts fonctionnaires de la Commission européenne'. Actes de la recherche en sciences sociales 166-167.1-2, pp. 38-53. DOI: 10.3917/arss.166.0039.

Hélénon, Valérie (2011). French Caribbeans in Africa: Diasporic Connections and Colonial Administration, 1880-1939. Basingstoke: Palgrave Macmillan, p. 203.

Hoisington, William A. (1995). Lyautey and the French Conquest of Morocco. New York: St. Martin's Press, p. 283.

Kirk-Greene, Anthony H. M. (1979). 'The Progress of Pro-Consuls: Advancement and Migration among the Colonial Governors of British African Territories'. Journal of Imperial and Commonwealth History 7.2, pp. 180-212. DOI: 10.1080/03086537908582528.

- (2000). Britain's Imperial Administrators, 1858-1966. London: Palgrave Macmillan, p. 347. DOI: $10.1057 / 9780230286320$.

Klein, Jean-François (2012). 'Du patronat colonial au patronat impérial : Un changement de paradigme'. Vingtième siècle. Revue d'histoire 114.2, pp. 67-81. DOI: 10.3917/vin.114.0067.

Laux, Claire, François-Joseph Ruggiu and Pierre Singaravélou (2009). At the Top of the Empire: European Elites in the Colonies (16th-20th Century). Bruxelles: Peter Lang, p. 326.

Lorin, Amaury (2004). Paul Doumer, gouverneur général de l'Indochine (1897-1902). Le tremplin colonial. Paris: L'Harmattan, p. 248.

Manceron, Gilles (2005). Marianne et les colonies. Une introduction à l'histoire coloniale de la France. Paris: La Découverte, p. 324.

Merle, Isabelle (2004). 'De la « légalisation » de la violence en contexte colonial. Le régime de l'indigénat en question'. Politix 66, pp. 137-162. DOI: 10.3406/polix.2004.1019.

Michel, Marc (1989). Galliéni. Paris: Fayard, p. 363.

Rezzi, Nathalie (2005). 'Servir la République :Prosopographie de hauts fonctionnaires coloniaux de 1880 à 1914'. PhD Thesis. Université d'Aix-Marseille, p. 602.

Rivet, Daniel (2002). Le Maghreb à l'épreuve de la colonisation. Paris: Hacette Littérature, p. 460.

Saada, Emmanuelle (2003). 'Citoyens et sujets de 1'Empire français. Les usages du droit en situation coloniale'. Genèses 53.4, pp. 4-24. DOI: 10.3917/gen.053.0004.

Singaravélou, Pierre (2008). Géographie, exploration et colonisation, XIX ${ }^{e}-X X^{e}$ siècle. Paris: Belin, p. 288.

Steinmetz, George (2008). 'The Colonial State as a Social Field: Ethnographic Capital and Native Policy in the German Overseas Empire before 1914'. American Sociological Review 73.4, pp. 589-612. DOI: $10.1177 / 000312240807300404$.

Stovel, Katherine and Mike Savage (2006). 'Mergers and Mobility: Organizational Growth and the Origins of Career Migration at Lloyds Bank'. American Journal of Sociology 111.4, pp. 1080-1121. DOI: 10.1086/498469. 
Stovel, Katherine, Mike Savage and Peter Bearman (2001). 'Class Formation and Localism in an Emerging Bureaucracy: British Bank Workers, 1880-1960'. International Journal of Urban and Regional Research 25.2, pp. 284-300. DOI: 10.1111/1468-2427.00312.

Viallet-Thévenin, Scott (n.d.). Les structures sociales de l'empire colonial français. L'émergence d'un espace élitaire autonome de 1871 á 1939. Document de travail, p. 25. 


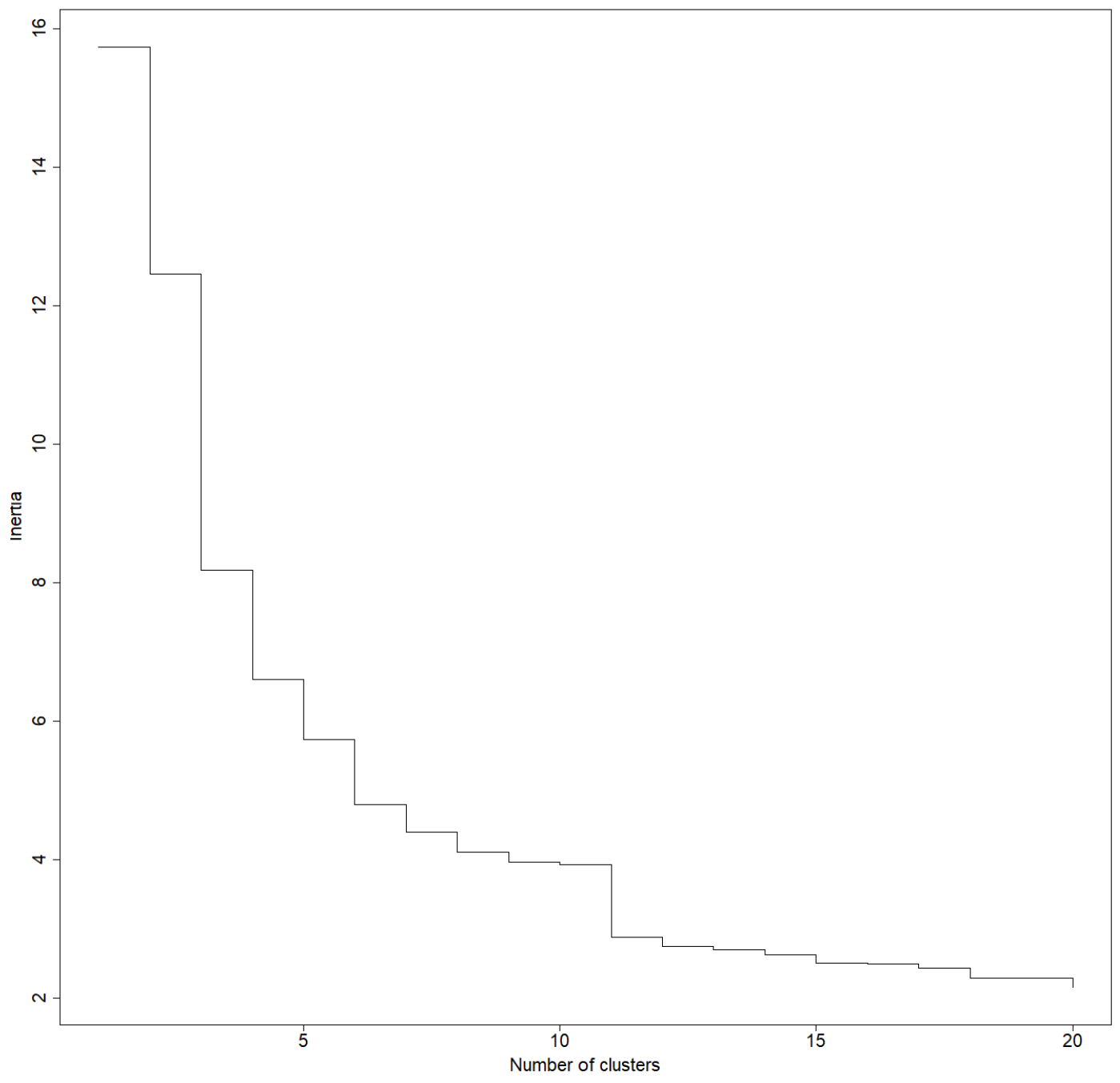

Figure 1 - Optimal number of classes based on pairwise dissimilarities 


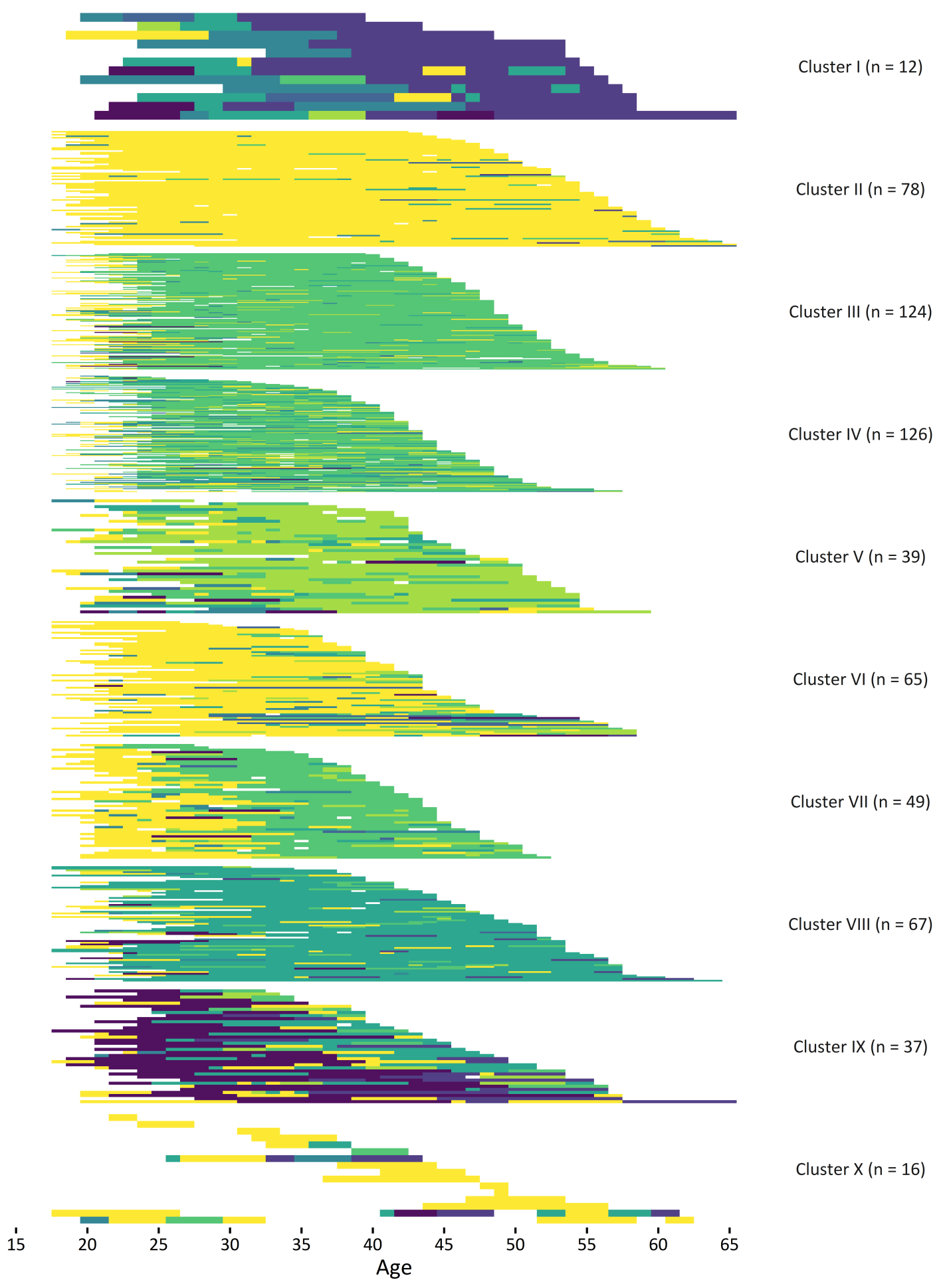

Type of organisations

$\begin{array}{lll}\square \text { Army } & \square \text { Central Colonial Adm. } \\ \square \text { Metropolitan Adm. } & \square \text { Local Colonial Adm. } \\ \square \text { Politics } & \square \text { Private Sector } & \square \text { NA }\end{array}$

Figure 2 - Distribution of states from age 18 to age 65 


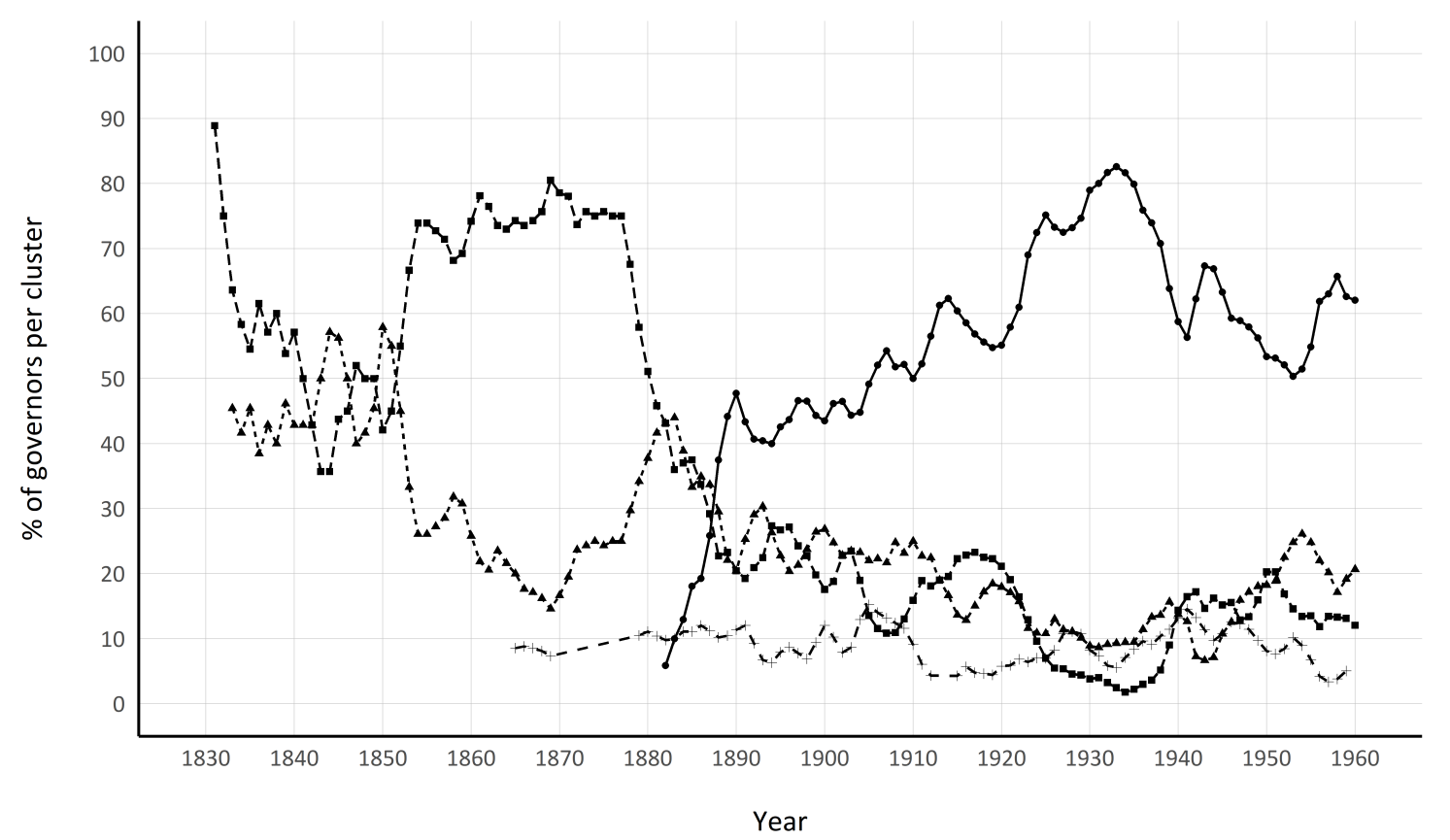

Notes: Shares are calculated as the ratio of the number of governors in each group of clusters over the total number of governors. Curves are smoothed using 3-year moving average. Group of clusters are defined as follows: Colonial administration (clusters III, IV, and V), Metropolitan space (clusters I, VIII, IX, and IX), Military (clusters II and VIII), Military-Colonial administration (cluster VI). Reading: in 1930, 79 per cent of governor positions were filled by individuals from the group of clusters Colonial administration.

Figure 3 - Share of governors per groups of clusters of career, 1830-1960 
Table 1 - Sources used for the data set construction

\begin{tabular}{lcc}
\hline Sources & $\begin{array}{c}\text { \# of } \\
\text { governors }\end{array}$ & $\begin{array}{c}\text { \% governors } \\
\text { covered }\end{array}$ \\
\hline ENFOM biographical dictionary & 150 & 23.6 \\
Léonore database & 410 & 64.5 \\
ANOM career records & 128 & 20.1 \\
Parliamentary biographical databases & 80 & 12.6 \\
Other sources & 211 & 33.2 \\
\hline
\end{tabular}

Notes: For some governors, we relied on more than one source of information. The cumulative percentage is therefore higher than 100.

Table 2 - Coding strategy: The career of Pierre Pasquier

\begin{tabular}{llllll}
\hline Position & Organisation & Region & Country & Start & End \\
\hline Administrator & Local colonial adm. & Tonkin & Indochina & 1898 & 1903 \\
Staff & Local colonial adm. & Tonkin & Indochina & 1903 & 1905 \\
District officer & Local colonial adm. & Tonkin & Indochina & 1905 & 1907 \\
Chief staff & Local colonial adm. & Cochinchina & Indochina & 1907 & 1911 \\
District officer & Local colonial adm. & Annam & Indochina & 1911 & 1914 \\
Chief staff & Central metropolitan adm. & France & France & 1914 & 1914 \\
Director adm. & Local colonial adm. & Tonkin & Indochina & 1915 & 1917 \\
Chief staff & Local colonial adm. & Tonkin & Indochina & 1917 & 1919 \\
Staff & Central metropolitan adm. & France & France & 1919 & 1921 \\
Governor & Local colonial adm. & Annam & Indochina & 1921 & 1926 \\
Governor-general & Central colonial adm. & Indochina & Indochina & 1926 & 1927 \\
Director adm. & Central metropolitan adm. & France & France & 1927 & 1928 \\
\hline
\end{tabular}

Sources: Pierre Pasquier, notice LH 19800035/308/41518. See Figures A1 and A2 in the Online Appendix for a copy of the original document. 
Table 3 - Descriptive statistics: Careers of French colonial governors

\begin{tabular}{lcccccccc}
\hline & $\begin{array}{c}\text { \% military } \\
\text { schools }\end{array}$ & \% ENFOM & $\begin{array}{c}\text { Age departure } \\
\text { for colonies }\end{array}$ & $\begin{array}{c}\text { Age } \\
\text { governor }\end{array}$ & $\begin{array}{c}\text { \% acting } \\
\text { governor }\end{array}$ & \% governor & $\begin{array}{c}\text { \% governor- } \\
\text {-general }\end{array}$ & $\begin{array}{c}\text { \# governors } \\
\text { per cluster }\end{array}$ \\
\hline Cluster 1 & 8 & 0 & 41 & 53 & 8 & 25 & 67 & 12 \\
Cluster 2 & 73 & 0 & 31 & 54 & 45 & 51 & 24 & 78 \\
Cluster 3 & 4 & 47 & 24 & 49 & 45 & 44 & 11 & 124 \\
Cluster 4 & 2 & 48 & 25 & 43 & 18 & 56 & 25 & 126 \\
Cluster 5 & 5 & 26 & 27 & 47 & 26 & 51 & 23 & 39 \\
Cluster 6 & 52 & 2 & 28 & 44 & 25 & 55 & 20 & 65 \\
Cluster 7 & 27 & 31 & 26 & 43 & 31 & 55 & 14 & 49 \\
Cluster 8 & 5 & 5 & 38 & 49 & 7 & 54 & 39 & 67 \\
Cluster 9 & 3 & 3 & 39 & 46 & 8 & 65 & 27 & 37 \\
Cluster 10 & 25 & 0 & 38 & 48 & 25 & 44 & 31 & 16 \\
\hline Average & 20 & 24 & 29 & 47 & 25 & 52 & 23 &
\end{tabular}

Notes: The total number of governors is 637. Information could not be retrieved for 24 governors. Descriptive statistics are calculated on a sample of 613 governors. \% acting governor, \% governor, and \% governor-general indicate, within each cluster, the highest rank achieved within the colonial administration. Reading: 13 per cent of individuals in cluster 1 graduated from a military school. In cluster 1 , the highest position reached by 20 per cent of individuals was governor. Similarly, in cluster 2 , the highest position reached by 51 per cent of individuals was acting governor. On average, 20 per cent of all individuals graduated from a military school and 24 per cent graduated from the ENFOM (École coloniale). 
Table 4 - Descriptive statistics: Sequence characteristics per cluster (in \%)

\begin{tabular}{lcccccccccc}
\hline & Cluster 1 & Cluster 2 & Cluster 3 & Cluster 4 & Cluster 5 & Cluster 6 & Cluster 7 & Cluster 8 & Cluster 9 & Cluster 10 \\
\hline Army & 4.6 & 94.7 & 7.9 & 7.3 & 6.7 & 72.8 & 34.6 & 7 & 10.7 & 71.3 \\
Central Colonial Adm. & 1.9 & 0.1 & 3.6 & 12.3 & 61.3 & 6 & 5.1 & 1.8 & 3.7 & 0 \\
Local Colonial Adm. & 1.9 & 1 & 82.6 & 55.1 & 17.1 & 7.3 & 51.7 & 5.5 & 3.7 & 5.9 \\
Metropolitan Adm. & 12.3 & 2 & 2.8 & 17.1 & 6.7 & 3.5 & 2.2 & 79.8 & 21.2 & 6.3 \\
Other Public Sector & 20 & 1.1 & 1.7 & 7 & 3.8 & 2 & 2.9 & 1.2 & 0.3 & 5.1 \\
Others & 3.8 & 0.9 & 0.3 & 0.6 & 0.7 & 6.6 & 0.8 & 0.3 & 0 & 0 \\
Politics & 49.6 & 0.3 & 0 & 0 & 0 & 0.1 & 0 & 1.7 & 12.3 & 8.9 \\
Private Sector & 5.9 & 0 & 1.1 & 0.8 & 3.5 & 1.8 & 2.6 & 2.6 & 48 & 2.5 \\
\hline Total duration & 30.8 & 32.7 & 24.6 & 17.8 & 22.7 & 20.7 & 19.3 & 25.7 & 24.0 & 7.4 \\
\hline
\end{tabular}

Notes: The total number of governors is 637. Information could not be retrieved for 24 governors. Descriptive statistics are calculated on a sample of 613 governors. Reading: In cluster 2, governors spent on average 94.7 per cent of their career in the Army. The average duration of professional careers before becoming governor in cluster 2 is 32.7 years. In Cluster 3, governors spent on average 82.6 per cent of their career in the local colonial administration. The average duration of professional careers before becoming governor in cluster 3 is 24.6 years. 
Table 5 - Descriptive statistics: Repartition of colonial governors per cluster per colonial federation (in \%)

\begin{tabular}{|c|c|c|c|c|c|c|c|c|c|c|c|}
\hline & Cluster 1 & Cluster 2 & Cluster 3 & Cluster 4 & Cluster 5 & Cluster 6 & Cluster 7 & Cluster 8 & Cluster 9 & Cluster 10 & Total \\
\hline Algeria, Morocco, Tunisia & 9.1 & 28.3 & 4 & 5.1 & 3 & 8.1 & 0 & 30.3 & 10.1 & 2 & 99 \\
\hline French West Africa & 0.3 & 5.4 & 21.3 & 31.9 & 8.3 & 10 & 12.5 & 4.2 & 4.5 & 2 & 408 \\
\hline French East Africa & 0 & 1.3 & 30.7 & 31.3 & 10 & 3.3 & 12.7 & 3.3 & 6 & 1.3 & 150 \\
\hline Madagascar & 0 & 5.7 & 14.3 & 25.7 & 17.1 & 14.3 & 2.9 & 14.3 & 5.7 & 0 & 35 \\
\hline Indochina & 1.4 & 8.9 & 26.5 & 23.4 & 5.8 & 11 & 12.4 & 5.5 & 3.4 & 1.7 & 291 \\
\hline Overseas France & 0 & 3.3 & 17.6 & 35.3 & 6.5 & 9.8 & 7.8 & 9.8 & 8.5 & 1.3 & 153 \\
\hline Other colonies & 1.3 & 4.5 & 16.5 & 33 & 6 & 9 & 9 & 11 & 9.5 & 2 & 200 \\
\hline
\end{tabular}

Notes: The total number of governors is 637. Information could not be retrieved for 24 governors, leaving a total of 1,183 positions as colonial governors. Other colonies includes: Mandate for Syria and the Lebanon, Overseas France, and French Somaliland. Reading: 30.7 per cent of individuals who held a position of governor in French East Africa originated from Cluster 3. In total, they were 150 nominations of colonial governors in French East Africa. 


\section{Online appendix}

\section{A Data and research design}

\section{A.1 Coding strategy}

The different values taken by the position variable are:

- soldier

- sub-officer

- junior officer

- senior officer

- general officer

- student

- clerk
- district officer

- administrator

- staff

- chief staff

- senior civil servant

- secretary-general

- colonial governor
- préfet

- parlementarian

- minister

- public sector (undetermined)

- private sector (undetermined)

The different values taken by the organisation variable are:

- colonial army

- navy

- metropolitan army

- metropolitan central administration

- metropolitan local administration
- colonial central administration

- colonial local administration

- private sector

- undetermined public sector

- undetermined private sector 


\section{A.2 Example of sources}

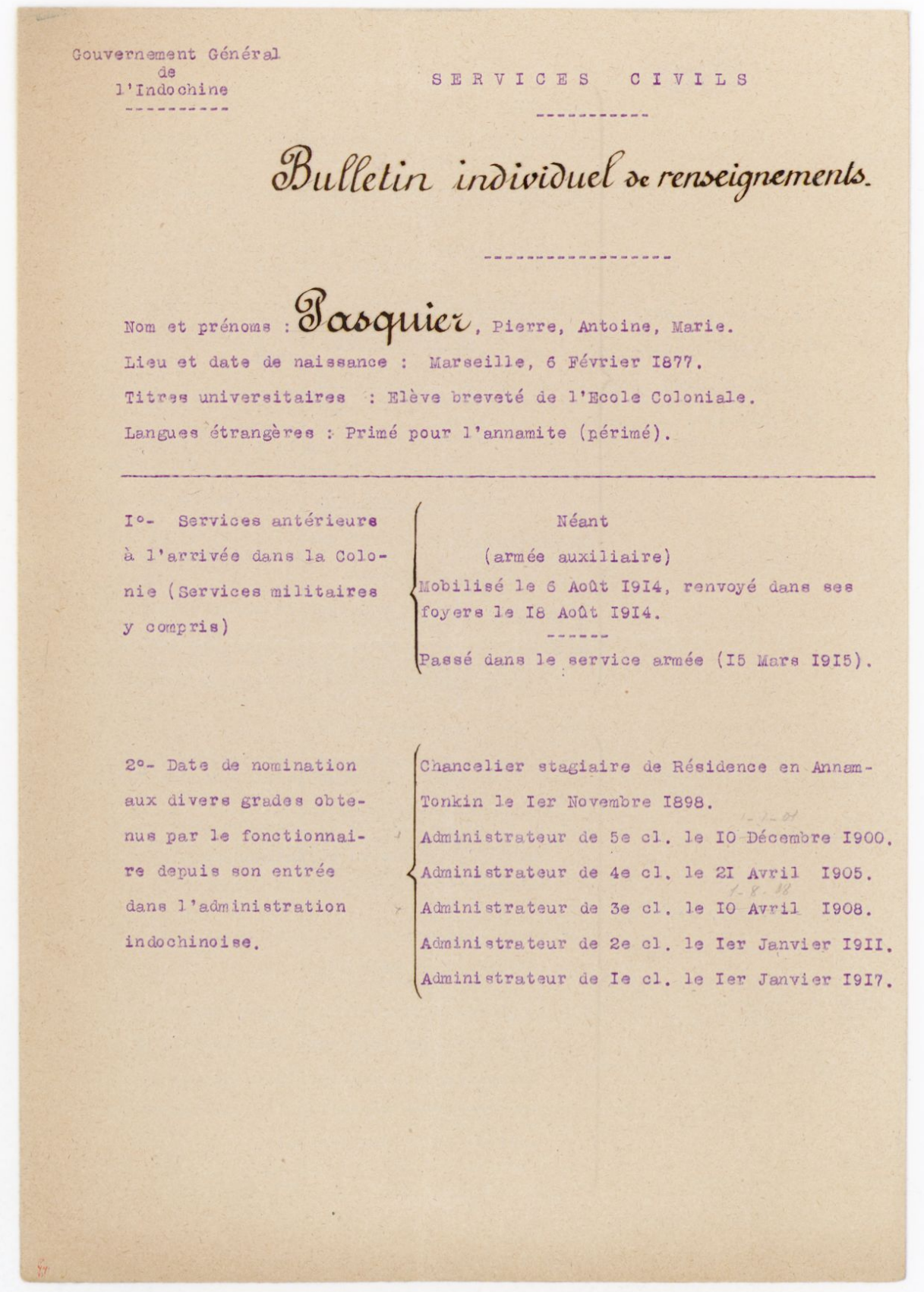

Sources: Pierre Pasquier, notice LH 19800035/308/41518.

Figure A1 - Career record of Pierre Pasquier 


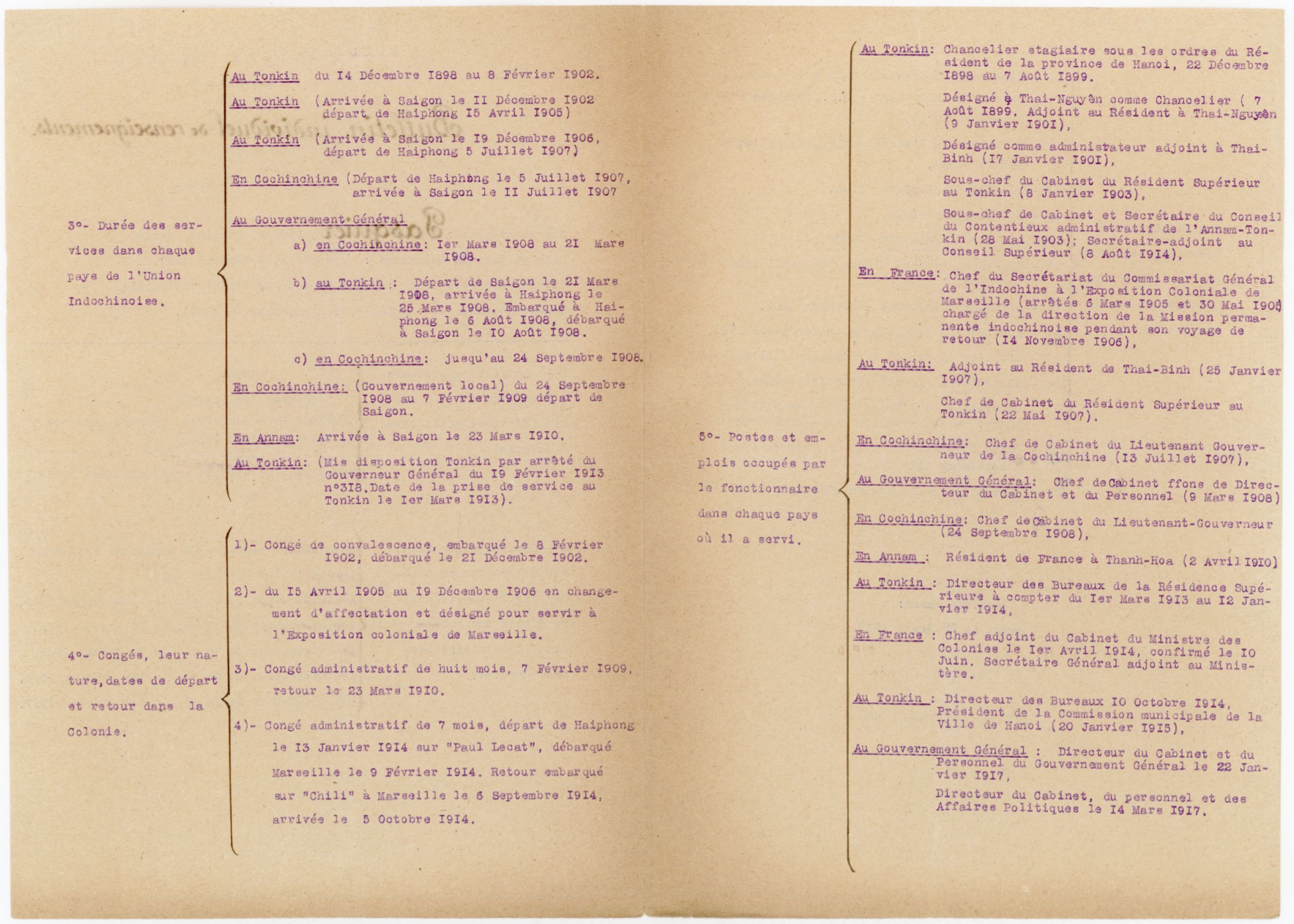

Sources: Pierre Pasquier, notice LH 19800035/308/41518.

Figure A2 - Career record of Pierre Pasquier 


\section{B Original quotes in French}

1. Gaston Fourn: «Je ne dissimule pas cependant les lacunes de la formation administrative de M. Fourn, mais il les rachète par une parfaite connaissance du pays, qu'aucun autre n'acquerra qu'après une longue période, perdue pour la mise en mains urgente de la colonie. »

2. Nicolas Gaden: "Magnifique officier qui a écrit une belle page en AOF et a fait brillamment son devoir pendant la guerre. Administrateur de haut mérite qui remplit avec une rare autorité les fonctions de commissaire. »

3. René Troadec: « Un des plus beaux caractères que j'ai connus: M. Troadec est d'un bloc calme, d'un équilibre parfait. Il a le goût et les sens des responsabilités. C'est un chef. »

4. René Troadec: "Il s'affirme comme un fonctionnaire complet, possédant les qualités d'un chef. »

5. Georges Rey: «M. Rey a pris le Sénégal en mains avec une maîtrise qui s'est imposée à tous dans sa colonie. Méthodique, précis et volontaire, c'est un Chef par sa personnalité, et un Chef Africain par son expérience nourrie, ordonnée et qui est allée au fonds des choses et des hommes de ce pays. »

6. Marcel Marchesson: «Fera un excellent administrateur lorsqu'il aura perfectionné sa culture générale administrative en servant encore quelques temps en sous ordre dans un chef-lieu de circonscription importante ou mieux, dans un bureau. »

7. Jules Brévié: «Belle formation administrative, profonde connaissance des milieux indigènes, culture générale, rectitude de jugement, et hautes qualités morales. »

8. Joseph Bride: «Il a surtout servi dans les cabinets, n'a que 9 mois de service en province, ses connaissances en administration indigène sont donc et ne peuvent être que limitées. 》

9. Fernand Lévecque: "Mais a plus de 30 ans de carrière politique. Il fut conseiller municipal, maire d'Amiens, conseiller général, puis député. Il est demeuré très politique, et je crois sincèrement que dans une colonie comme le Sénégal, l'heure n'est pas encore d'agiter les questions qui nous préoccupent en France. Le charger des vieilles colonies dont le fonctionnement est à peu près semblable à celui de la France. » 
10. René Petitbon: «Je dois attirer votre attention sur la nécessité de confier ce territoire politiquement délicat (le Dahomey) à un gouverneur ayant une connaissance de la mentalité et de la politique autochtone. »

11. René Petitbon: "Je crois en effet indispensable de vous signaler la réaction de l'administration et du gouverneur qui accepteront difficilement d'être inspectés par un étranger à leur corps. »

12. Henri Lejeune: "Il est rompu aux indigènes et administrations de nos territoires africains, tandis qu'il semble peu préparé à l'administration de nos colonies à conseils généraux, et aux luttes électorales. » 